\title{
Dental emergencies in Burkina Faso Armed Forces
}

\section{Nagłe przypadki stomatologiczne u żołnierzy sił zbrojnych Burkina Faso}

\author{
Raoul Bationo ${ }^{1, A, C, D}$, Wendpouiré P. L. Guiguimdé, E, F, Hamidou Ouédraogo1, B, Blintim Somé1, B \\ 1 Medical Center of General Aboubacar Sangoulé Lamizana, Burkina Faso \\ 2 Health Department, Ouaga I University Professor Joseph Ki-Zerbo, Burkina Faso \\ A - research concept and design; $\mathrm{B}$ - collection and/or assembly of data; $\mathrm{C}$ - data analysis and interpretation; \\ $\mathrm{D}$ - writing the article; $\mathrm{E}$ - critical revision of the article; $\mathrm{F}$ - final approval of article
}

\section{Address for correspondence}

Raoul Bationo

E-mail: raobat10@yahoo.fr

Funding sources

none declared

Conflict of interest

none declared

Received on September 9, 2016

Revised on November 9, 2016

Accepted on November 23, 2016
DOI

$10.17219 / \mathrm{dpm} / 67315$

Copyright

(C) 2017 by Wroclaw Medical University

and Polish Dental Society

This is an article distributed under the terms of the

Creative Commons Attribution Non-Commercial License

(http://creativecommons.org/licenses/by-nc-nd/4.0/)

\section{Abstract}

Background. Dental emergencies affect the mission of deployed units. During military operations, the definition of dental emergency is different from that which is commonly accepted in dentistry. There is no notion of seriousness or need for urgent care. A considerable number of studies concerning American, French and other armies exist in the literature. This is the first study in Burkina Faso.

Objectives. The purpose of this study was to quantify the dental emergency rate observed in Burkina Faso soldiers deployed in Mali and to determine the percentage of dental emergencies.

Material and methods. All the reasons for dental emergencies, between February 2015 and January 2016, were documented from the data of the register of clinical activities from the dental clinic of Timbuktu level 1 hospital.

Results. Caries accounted for $47.1 \%$ of dental emergencies. The second most common reason for visiting the dental clinic was periodontal diseases (19.3\%), followed by lost crowns (9.7\%). Fractured teeth caries accounted for $9 \%$ of emergencies and $7.1 \%$ of emergencies were attributed to infections. The remaining visits for dental emergencies accounted for 7.8\%. The dental emergency rate for Burkina Faso Forces based in Mali is 182 per 1,000 soldiers per year.

Conclusions. Caries are the main reason why soldiers went to the dental clinic. Dental emergencies can significantly affect the mission of the deployed unit.

Key words: dental emergencies, operational capability, deployed soldiers, Burkina Faso Army

Słowa kluczowe: nagłe przypadki stomatologiczne, zdolność operacyjna, rozlokowani żołnierze, armia Burkina Faso 
Dental pathologies account for a great deal of the medical emergencies encountered by the deployed military personnel. It has been demonstrated that as many as $22 \%$ of all emergency health visits during field training exercises were attributable to dental problems. ${ }^{1}$

Dental emergencies can significantly affect the mission of the deployed unit with the following repercussions ${ }^{2}$ : A decreased level of the soldiers' individual performance, inability of the soldiers to accomplish their mission, unavailability of the soldiers with dental problems in case of a visit to a dental care facility is necessary, unavailability of the soldiers who escort a patient to a dental care facility and the potential risks associated to the movements in theaters of operations.

During military operations, there is no notion of seriousness or need for urgent care in the definition of a dental emergency. This study uses a consensus definition: "A condition of oral disease, trauma or loss of function, or other concern that causes a patient to seek immediate dental treatment". ${ }^{3}$

The mission of the military dentists will be to preserve the operational capability of troops by avoiding time losses due to a dental issue.

So far, there have been many studies concerning dental emergency rates of soldiers in theaters of operations. ${ }^{4-8}$ The most recent, by Gunepin et al., ${ }^{6}$ was conducted in Mali, as is this study.

Our study aims to assess the impact of dental problems on the operational capability of Burkina Faso armed Forces by counting the reasons for dental emergencies.

\section{Material and methods}

The present study investigated the rate of dental emergency visits from a patient population of 850 Burkina Faso soldiers deployed as part of the United Nations Multidimensional Integrated Stabilization Mission in Mali (MINUSMA) from February 2015 to January 2016.

The register of clinical activities from the dental clinic of Timbuktu level 1 hospital served as a basis for data collection.

Only the causes of dental emergencies in Burkina Faso soldiers have been taken into account.

The rate of dental emergencies per 1,000 soldiers was calculated by dividing the total number of initial emergency visits by the total number of deployed soldiers and then multiplying by 1,000 .

The values were analyzed using Epi Info v. 3.5 .3 software. The statistical test was Mantel-Haenszel Chi-square and the corresponding odds ratios were presented with $\mathrm{p}<0.05$.

\section{Results}

The frequency of each cause of the dental emergency is presented in Table 1.
Table 1. Frequency of reasons for dental emergencies (DEs)

\begin{tabular}{|l|c|c|}
\hline Cause of DEs & Frequency & $\begin{array}{c}\text { Percentage } \\
(\mathrm{n}=155)\end{array}$ \\
\hline Caries & 73 & 47.1 \\
Infections & 11 & 7.1 \\
Lost crowns & 15 & 9.7 \\
Pericoronitis & 3 & 2 \\
Periodontal diseases & 30 & 19.3 \\
Fractured teeth no caries & 2 & 1.3 \\
Fractured teeth caries & 14 & 9 \\
Others & 7 & 4.5 \\
\hline
\end{tabular}

One hundred fifty-five (155) dental emergency visits were recorded. This accounts for 182 per 1,000 soldiers per year. Most of the emergencies (47.1\%) were due to caries.

Periodontal diseases were the second most common reason for visiting the dental clinic (19.3\%), followed by lost crowns $(9.7 \%)$. Fractured teeth caries accounted for $9 \%$ of emergencies and $7.1 \%$ of emergencies were attributed to infections. The remaining combined visits for dental emergencies accounted for $7.8 \%$.

\section{Discussion}

Caries appear as the main dental problem of deployed military personnel, accounting for $47.1 \%$ of causes of dental emergencies.

Data from our study shows that caries, periodontal diseases and lost crowns are the 3 most common causes of dental emergencies in Burkina Faso Army. The results of American, English, Australian and French studies ${ }^{6,9-12}$ are different; with caries, fractured teeth and/or crowns without caries and pulpitis as the most common reasons for the dental emergency.

A dental literature review shows that caries are the main cause of dental emergency regardless of the nationality of soldiers, the theater of operations and the deployment time (Table 2).

The dental emergency rate expressed the difference between armies opposite to the percentage of each cause of dental emergencies.

The literature reported rates from 293 to 700 per 1,000 soldiers per year for French Army, 2,4,6,13 and from 86 to 259 per 1,000 soldiers per year for U.S., Canadian and British Forces. ${ }^{9-12,14}$ So Burkina Faso soldiers have the same dental problems than the other armies, but in small number comparatively to the French Forces.

Studies by Chaffin et al. ${ }^{7}$ and Moss $^{8}$ supported these findings, as caries were responsible for more than $1 / 2$ of all dental emergencies, if the defective restorations are included in the caries category. 
Table 2. Rate of the dental emergency (DE) at the operations and frequency of caries in Armies

\begin{tabular}{|c|c|c|c|c|c|c|c|}
\hline Authors & Army & Place & Duration & Supported population & Number of DE & DE rate & $\%$ of caries \\
\hline Gunepin et $a l^{4}$ & FR & Afghanistan & 2 months & 3,750 & 210 & 293 & 43 \\
\hline Gunepin et al. ${ }^{6}$ & FR & Mali & 10 months & NR & 556 & NR & 44.6 \\
\hline Dunn ${ }^{15}$ & US & Oman & 6 months & 1,972 & 137 & NR & 38.4 \\
\hline Bationo et al. & BFA & Mali & 12 months & 850 & 155 & 182 & 47.1 \\
\hline
\end{tabular}

Our frequency of caries in dental emergencies (47.1\%) is not significantly different from the results observed in the French Army in Mali (44.6\%) ( $\mathrm{p}=0.71){ }^{6}$

Every effort is made to give deployed military personnel a dental examination to identify correctable conditions or disease before their arrival to theaters of operations.

The objective of the examination is to assess for each soldier their oral condition and the risk of a dental emergency occurrence during the next 12 months. ${ }^{16}$

After a fitness examination, soldiers with dental pathologies must undergo dental care prior to their deployment.

In theaters of operations, dental emergencies for carious reasons are related to preexisting lesions may worsen during missions because of the deterioration of living conditions (decrease of oral hygiene).

All soldiers must have access during missions to oral hygiene commodities that can contribute to the improvement of their oral health.

These commodities can be available as a dental kit included in a field hygiene kit. The U.S. Army uses the Health and Comfort Pack (HCP) type I. ${ }^{17}$

The individual combat pack for each deployed soldier from Burkina Faso Armed Forces includes 1 toothbrush with toothpaste. This is very insufficient for a 12-month long mission, so the renewal of this mini kit is the soldier's responsibility.

Dental care was only given to soldiers who came for a visit. It would therefore be desirable for a dentists to schedule routine visits at least every 6 months so as to allow them to treat dental pathologies and also perform routine teeth cleaning.

Unfortunately, in Burkina Faso the oral health program does not take into account the strategy of fluoride application on the teeth. Thus, it would be beneficial for the Armed Forces to adopt this strategy for the prevention of caries in deployed military personnel.

The use of xylitol in addition to daily oral hygiene can also help reduce the frequency of dental emergencies among soldiers in operations. Finland and the USA have already incorporated this molecule in their Armed Forces. ${ }^{18}$

\section{Conclusions}

Dental emergencies of soldiers have a direct effect on the capability of a deployed Force to accomplish its assigned mission.

The dental emergency rate for Burkina Faso Army peacekeeping operation in Mali was determined to be 182 per 1,000 soldiers per year. This statistic is lower than reports of French Forces. The primary etiologic factor in the current study was caries $(47.1 \%)$.

To prevent the occurrence of these emergencies, all soldiers must have access during missions to oral hygiene commodities. The military dentists must provide soldiers with emergency and non-emergency care prior to their deployment and also schedule routine visits during operations.

\section{References}

1. Grover PS, Carpenter WM, Allen GW. Dental emergencies occurring among United States Army recruits. Milit Med. 1983;148:56-57.

2. Gunepin M, Derache F. Impact opérationnel et prise en charge des pathologies bucco-dentaires dans le cadre des opérations extérieures. Médecine et Armées 2009;37:313-318 [in French].

3. Simecek J. Consensus statements. Milit Med. 2008;173:59.

4. Gunepin M, Derache F, Ausset I, Berlizot P, Simecek J. The rate of dental emergencies in French Armed Forces deployed to Afghanistan. Milit Med. 2011;176:828-832.

5. Fenistein B. Pourquoi tant de consultants dentaires en Opex? Médecine et Armées 2004;32:123-126 [in French].

6. Gunepin M, Benmansour A, Derache F, Maresca S, Blatteau JE, Risso JJ. Motifs de consultation en urgence au cabinet dentaire du groupement médico-chirurgical de Gao: Quelles leçons en tirer? Médecine et Armées 2015;43:345-351 [in French].

7. Chaffin J, King JE, Fretwell LD. U.S. Army dental emergency rates in Bosnia. Milit Med. 2001;166:1074-1078.

8. Moss DL. Dental emergencies during SFOR 8 in Bosnia. Milit Med. 2002;167:904-906.

9. Dunn WJ, Langsten RE, Flores S, Fandell JE. Dental emergency rates at two expeditionary medical support facilities supporting operations enduring and Iraqi Freedom. Milit Med. 2004;169:510-514.

10. Mahoney G, Coombs M. A literature review of dental casualty rates. Milit Med. 2000;165:751-756.

11. Mahoney D. The operational dental officer in the ADF. ADF Health 2003;4:40-44.

12. Moss D. Dental emergencies during Stabilization Force 8 in Bosnia. Milit Med. 2002;167:904-906.

13. Gunepin M, Limonet A, Derache F. Intérêts et limites de l'utilisation de la classification internationale des maladies dans le recueil de l'activité dentaire en opération. Médecine et Armées 2010;38:417-424 [in French].

14. Simecek JW, Colthirst P, Wojcik BE, Eikenberg S, Guerrero AC, Fedorowicz A, Szeszel-Fedorowicz W, DeNicolo P. The incidence of dental disease nonbattle injuries in deployed U.S. Army personnel. Milit Med. 2014;179:666-673.

15. Dunn WJ. Dental emergency rates at an expeditionary medical support facility supporting operation enduring Freedom. Milit Med. 2004;169:349-353.

16. NATO standard. AMedP-4.4. Dental fitness standards for military personnel and the NATO dental fitness classification system. Edition A Version 1, 2014

17. Gunepin M, Derache F. Approche militaire américaine de l'optimisation de la mise en condition dentaire des forces. Médecine et Armées. 2008;36:323-331 [in French].

18. Gunepin M, Derache F. Impact du xylitol sur le risque carieux - implications militaires. Médecine et Armées. 2010;38:369-380 [in French]. 